\title{
The Effect of Lysophosphatidic Acid during In Vitro Maturation of Bovine Oocytes: Embryonic Development and mRNA Abundances of Genes Involved in Apoptosis and Oocyte Competence
}

\author{
Dorota Boruszewska, ${ }^{1}$ Ana Catarina Torres, ${ }^{2}$ Ilona Kowalczyk-Zieba, ${ }^{1}$ Patricia Diniz, \\ Mariana Batista, ${ }^{2}$ Luis Lopes-da-Costa, ${ }^{2}$ and Izabela Woclawek-Potocka ${ }^{1}$ \\ ${ }^{1}$ Department of Reproductive Immunology and Pathology, Institute of Animal Reproduction and Food Research, \\ Polish Academy of Sciences, 10-747 Olsztyn, Poland \\ ${ }^{2}$ CIISA, Faculty of Veterinary Medicine, University of Lisbon, 1300-477 Lisbon, Portugal \\ Correspondence should be addressed to Izabela Woclawek-Potocka; i.woclawek-potocka@pan.olsztyn.pl
}

Received 12 November 2013; Revised 18 January 2014; Accepted 28 January 2014; Published 4 March 2014

Academic Editor: Anna Chełmonska-Soyta

Copyright (C) 2014 Dorota Boruszewska et al. This is an open access article distributed under the Creative Commons Attribution License, which permits unrestricted use, distribution, and reproduction in any medium, provided the original work is properly cited.

\begin{abstract}
In the present study we examined whether LPA can be synthesized and act during in vitro maturation of bovine cumulus oocyte complexes (COCs). We found transcription of genes coding for enzymes of LPA synthesis pathway (ATX and PLA2) and of LPA receptors (LPAR 1-4) in bovine oocytes and cumulus cells, following in vitro maturation. COCs were matured in vitro in presence or absence of LPA $\left(10^{-5} \mathrm{M}\right)$ for $24 \mathrm{~h}$. Supplementation of maturation medium with LPA increased mRNA abundance of FST and GDF9 in oocytes and decreased mRNA abundance of CTSs in cumulus cells. Additionally, oocytes stimulated with LPA had higher transcription levels of $B C L 2$ and lower transcription levels of $B A X$ resulting in the significantly lower $B A X / B C L 2$ ratio. Blastocyst rates on day 7 were similar in the control and the LPA-stimulated COCs. Our study demonstrates for the first time that bovine COCs are a potential source and target of LPA action. We postulate that LPA exerts an autocrine and/or paracrine signaling, through several LPARs, between the oocyte and cumulus cells. LPA supplementation of maturation medium improves COC quality, and although this was not translated into an enhanced in vitro development until the blastocyst stage, improved oocyte competence may be relevant for subsequent in vivo survival.
\end{abstract}

\section{Introduction}

During the last decade, the functional role of lysophosphatidic acid (LPA) in the female reproduction has been the object of an increasing number of reports [1]. LPA, the simplest and at the same time one of the most potent phospholipids, has been regarded as an important signaling molecule participating in various biological processes, such as cell proliferation [2], differentiation [3], survival [4, 5], morphogenesis [6], and cytokine secretion [7]. This molecule is produced from membrane phospholipids by two main pathways/enzymes: autotaxin (ATX) and phospholipase A2
(PLA2) $[8,9]$. In mammals, LPA exerts its action via at least six high affinity, transmembrane G-protein-coupled receptor (GPCR) types: LPAR1-LPAR6 and possibly through a nuclear receptor PPAR $\gamma$ [10-14]. Expression of LPARs is tissue and cell specific [15]. An association of LPA signaling with regulation of reproductive function first was described in women $[16]$ and then in farm animals including ruminants $[17,18]$. Our previous studies showed that LPA is locally produced and acts in the bovine uterus $[18,19]$ and ovary $[20,21]$. We documented that the intravaginal administration of LPARs antagonist decreases pregnancy rate and that infusion of LPA prevents spontaneous luteolysis, prolongs the functional 
lifespan of the corpus luteum (CL), and also stimulates luteotropic prostaglandin $(\mathrm{PG}) \mathrm{E}_{2}$ synthesis in heifers $[18,22]$. Additionally, in in vitro studies, we found a stimulatory effect of LPA on progesterone $\left(\mathrm{P}_{4}\right)$ synthesis and interferon (IFN) $\tau$ action in the steroidogenic cells of the bovine CL [20] and on luteotropic $\mathrm{PGE}_{2}$ synthesis in bovine endometrial cells [22]. Our recently published data demonstrates that bovine granulosa cells of the follicle are also the site of LPA synthesis and the target for LPA action [21]. In the above mentioned study [21], LPA exerted an autocrine and paracrine action in granulosa cells through several LPARs and stimulated estradiol $\left(\mathrm{E}_{2}\right)$ synthesis via increased FSH receptor (FSHR) and $17 \beta$-hydroxysteroid dehydrogenase $(17 \beta-H S D)$ expression. These results led us to hypothesize that cumulus oocyte complexes (COCs) may be the source and the target of LPA action during oocyte maturation. Oocyte maturation involves changes in the nucleus [23-25] and cytoplasm [26-29], and granulosa cells modulate chromatin configuration [30, 31], transcriptional activity [31], and cytoplasmic maturation [30, 32]. This bidirectional communication between the oocyte and surrounding cumulus cells is essential for proper oocyte maturation and determinates subsequent oocyte competence.

There are two major premises that initiated our studies on the effect of LPA supplementation of maturation medium on the communication between the oocyte and surrounding cumulus cells defined as embryonic development and the expression of genes involved in apoptosis and oocyte competence in oocytes and cumulus cells. The first premise documented by Boruszewska et al. [21] is concerned about an autocrine and paracrine action of LPA in the granulosa cells of the bovine ovarian follicle. The second premise regards the continuous, unrestrained development of the methods of in vitro culture of bovine embryos using variously supplemented media.

In the present study we examined whether LPA can be synthesized and act during in vitro maturation of bovine COCs. We also determined the effect of LPA supplementation of maturation medium on mRNA abundance of oocyte quality markers (follistatin-FST, growth and differentiation factor 9-GDF9, bone morphogenetic protein 15-BMP15, cysteine proteinases-cathepsins: CTSB, CTSK, CTSS, and CTSZ) and genes involved in apoptosis ( $B C L 2$ and $B A X$, as well as $B A X / B C L 2$ ratio) in oocytes and cumulus cells. Finally, we evaluated the effect of LPA supplementation of maturation medium on cleavage and blastocyst rates on day 2 and day 7 of in vitro culture of bovine embryos, respectively.

\section{Materials and Methods}

2.1. Chemicals and Suppliers. All chemicals and reagents for in vitro culture were purchased from Sigma Aldrich (Germany) unless otherwise stated. Plastic dishes, fourwell plates, and tubes were obtained from Nunc (Thermo Scientific, Denmark). All chemicals for reverse transcription were acquired from Invitrogen (Life Technologies, USA).

2.2. Oocyte and Cumulus Cell Collection. All experimental procedures were approved by the Local Animal Care and
Use Committee in Olsztyn, Poland (Agreement number $34 / 2012 / N)$. Ovaries were collected from slaughtered cows and transported to the laboratory in sterile PBS at $37^{\circ} \mathrm{C}$. COCs were obtained by aspiration from subordinate ovarian follicles, less than $5 \mathrm{~mm}$ in diameter. Only COCs consisting of oocytes with homogeneous ooplasm without dark spots and surrounded by at least three layers of compact cumulus cells were selected for the study. COCs were chosen under a stereomicroscope and washed two times in wash medium (TCM199; \#M2154) supplemented with $25 \mu \mathrm{g} / \mathrm{mL}$ amphotericin b (\#A2942), 5 USP/mL heparin (\#H3393), 25 mM HEPES (\#H3784), $5 \mathrm{mM}$ sodium bicarbonate (\#S4019), $0.2 \mathrm{mM}$ sodium pyruvate (\#P3662), and $1 \%$ fetal bovine serum (FBS; $\# 12106 \mathrm{C}$ ) and subsequently washed in maturation medium.

2.3. Oocyte Maturation. 26 groups of 25 immature COCs were cultured in four-well plates (\#144444) containing $400 \mu \mathrm{L}$ of maturation medium (TCM-199 supplemented with $0.4 \mathrm{mM}$ L-glutamine (\#G5763), $0.05 \mathrm{mg} / \mathrm{mL}$ gentamicin (\#G1272), $1 \mu \mathrm{L} / \mathrm{mL}$ insulin-transferrin-sodium selenite, (ITS, \#I3146), $10 \mathrm{UI} / \mathrm{mL}$ pregnant mare's serum gonadotropin (PMSG), and $5 \mathrm{UI} / \mathrm{mL}$ chorionic gonadotropin human (hCG; PG600, Intervet International, Boxmeer, The Netherlands) and $15 \% v / v$ FBS) under $400 \mu \mathrm{L}$ of mineral oil (\#M5310), as recently described by Torres et al. [33]. Two experimental groups were randomly generated for analyses from COCs: exposed to LPA agonist (LPA; 1-oleoyl-sn-glycerol 3-phosphate sodium salt; $10^{-5} \mathrm{M}$; \#L7260) or PBS (control group) during in vitro maturation. The dose of LPA was taken from earlier reports on humans and rodents [34-36]. Subsequently COCs were matured in vitro for $24 \mathrm{~h}$ at $39^{\circ} \mathrm{C}$ under $5 \% \mathrm{CO}_{2}$ in humidified air. After in vitro maturation, COCs were processed for total RNA extraction (for mRNA expression analysis) or in vitro fertilized and cultured (for cleavage and blastocyst rates analysis).

\subsection{Sample Collection for RNA Isolation and Reverse Tran-} scription. After $24 \mathrm{~h}$ of in vitro maturation, for total RNA extraction (for mRNA expression analysis), the oocytes from 5 pools of each experimental group (control or LPA treated) were separated from cumulus cells by vortexing. Each pool consisted of 25 denuded oocytes and all cumulus cells separated from the respective oocytes. The oocytes and cumulus cells were suspended in the Extraction Buffer and processed for RNA isolation according to manufacturer's instructions (\#KIT0204, Arcturus PicoPure RNA Isolation Kit, Applied Biosystems, Life Technologies, USA). DNase treatment was performed for the removal of genomic DNA contamination using RNase-free DNase Set (\#79254, Qiagen, Germany). Samples were stored at $-80^{\circ} \mathrm{C}$ until reverse transcription. The reverse transcription (RT) was performed using oligo (dT)12-18 primers (\#18418-012) by Super Script III reverse transcriptase (\#18080-044) in a total volume of $20 \mu \mathrm{L}$ to prime the $\mathrm{RT}$ reaction and produce $\mathrm{cDNA}$. The $\mathrm{RT}$ reaction was carried out at $65^{\circ} \mathrm{C}$ for $5 \mathrm{~min}$ and $42^{\circ} \mathrm{C}$ for $60 \mathrm{~min}$ followed by a denaturation step at $70^{\circ} \mathrm{C}$ for $15 \mathrm{~min}$. RNase $\mathrm{H}$ (\#18021-071) was used to degrade the RNA strand of an RNA-DNA hybrid 
$\left(37^{\circ} \mathrm{C}\right.$ for $\left.20 \mathrm{~min}\right)$. RT products were diluted four times and were stored at $-20^{\circ} \mathrm{C}$ until real-time PCR amplification.

2.5. Quantitative Real-Time PCR. The quantification of mRNA for the examined genes was conducted by realtime PCR using specific primers for LPAR1, LPAR2, LPAR3, LPAR4, ATX, PLA2, FST, GDF9, BMP15, CTSB, CTSK, CTSS, $C T S Z, B C L 2$, and $B A X$. The results of mRNA expression were normalized to glyceraldehyde-3-phosphate dehydrogenase (GAPDH, an internal control) mRNA expression and were expressed as arbitrary units. The primers were designed using an online software package (http://bioinfo.ut.ee/primer3/). Primer sequences and the sizes of the amplified fragments of all transcripts are shown in Table 1. Real-time PCR was performed with an ABI Prism 7900 (Applied Biosystems, Life Technologies, USA) sequence detection system using Maxima SYBR Green/ROX qPCR Master Mix (\#K0222, Fermentas, Thermo Scientific, USA). The PCR reactions were performed in 96-well plates. Each PCR reaction well $(20 \mu \mathrm{L})$ contained $2 \mu \mathrm{L}$ of RT product, $5 \mathrm{pmol} / \mu \mathrm{L}$ forward and reverse primers each, and $10 \mu \mathrm{L}$ SYBR Green PCR master mix. In each reaction we used a quantity of cDNA equivalent to 0.25 oocyte or cumulus cells. Real-time PCR was performed under the following conditions: $95^{\circ} \mathrm{C}$ for $10 \mathrm{~min}$, followed by 40 cycles of $94^{\circ} \mathrm{C}$ for $15 \mathrm{sec}$ and $60^{\circ} \mathrm{C}$ for $60 \mathrm{sec}$. Subsequently in each PCR reaction melting curves were obtained to ensure single product amplification. In order to exclude the possibility of genomic DNA contamination in the RNA samples, the reactions were also performed either with blank-only buffer samples or in absence of the reverse transcriptase enzyme. The specificity of the PCR products for all examined genes was confirmed by gel electrophoresis and by sequencing. The efficiency range for the target and the internal control amplifications balance was between 95 and $100 \%$. For the relative quantification of the mRNA expression levels real-time PCR Miner algorithm was used (http://www.miner.ewindup.info/version2).

2.6. In Vitro Fertilization and Embryo Culture. Procedures of in vitro fertilization and embryo culture were performed according to Torres et al. [33]. Briefly, for in vitro fertilization (for developmental capacity analysis), 16 pools of 25 COCs were washed in fertilization medium (modified Tyrode's medium (TALP) supplemented with $5.4 \mathrm{USP} / \mathrm{mL}$ heparin, $10 \mathrm{mM}$ penicillamine (\#P4875), $20 \mathrm{mM}$ hypotaurine (\#H1384), $0.25 \mathrm{mM}$ epinephrine (\#E1635), and $0.1 \mathrm{mg} / \mathrm{mL}$ gentamicin solution. For in vitro insemination, frozenthawed semen was used. After thawing, semen was layered below capacitation medium (TALP medium supplemented with $72.72 \mathrm{mM}$ pyruvic acid sodium pyruvate and $0.05 \mathrm{mg} / \mathrm{mL}$ gentamicin) and incubated for $1 \mathrm{~h}$ at $39^{\circ} \mathrm{C}$ in a $5 \% \mathrm{CO}_{2}$ in humidified air atmosphere to allow the recovery of motile sperm through the swim-up procedure. After incubation, the upper two-thirds of the capacitation medium were recovered, centrifuged at $200 \times \mathrm{g}$ for $10 \mathrm{~min}$, the supernatant removed, and the sperm pellet diluted in an appropriate volume of fertilization medium to give a final concentration of $10^{6} \mathrm{sperm} / \mathrm{mL}$. Groups of 25 COCs were coincubated with spermatozoa in four-well dishes containing $400 \mu \mathrm{L}$ of fertilization medium under $400 \mu \mathrm{L}$ of mineral oil for $48 \mathrm{~h}$ at $39^{\circ} \mathrm{C}$ in a $5 \% \mathrm{CO}_{2}$ humidified air atmosphere. The day of in vitro insemination was considered day 0 . At $48 \mathrm{~h}$ postinsemination (hpi) embryos were separated from cumulus cells by vortexing and washed three times in wash medium. The cleavage rates were assessed and embryos with four or more cells were placed in four-well dishes containing $400 \mu \mathrm{L}$ culture medium (SOF; synthetic oviductal fluid medium described by Holm et al. [37] supplemented with amino acids: $30 \mu \mathrm{L} / \mathrm{mL}$ BME (\#B6766) and $10 \mu \mathrm{L} / \mathrm{mL}$ MEM (\#M7145), $0.34 \mathrm{mM}$ trisodium-citrate (\#6448.1000, Merck Millipore, Germany), 2.77 mM myo-inositol (\#I7508), $1 \mu \mathrm{L} / \mathrm{mL}$ gentamicin, $1 \mu \mathrm{L} / \mathrm{mL}$ ITS, and $5 \% v / \nu$ FCS) overlaid with $400 \mu \mathrm{L}$ mineral oil. Culture was carried out at $39^{\circ} \mathrm{C}$ in a $5 \% \mathrm{CO}_{2}$ in air with high humidity. Blastocyst numbers were determined on day 7 postinsemination. The rates of development to the blastocyst stage were calculated based on the total number of matured oocytes.

2.7. Statistical Analysis. All data concerning expression patterns of target genes are presented as mean \pm SEM. One-way ANOVA followed by Newman-Keuls' multiple comparison test was used to determine differences in mRNA expression of LPARs in oocytes and cumulus cells (GraphPad PRISM 6.0). Differences in transcription levels of the remaining genes were analyzed by Student's $t$-test for independent pairs. Cleavage and blastocyst rates were analyzed by Fisher's exact test. Differences were considered statistically significant at the 95\% confidence level $(P<0.05)$.

\section{Results}

3.1. The Expression Patterns of LPARs (LPAR1, LPAR2, LPAR3, and LPAR4) and Enzymes Involved in LPA Synthesis (ATX and PLA2) in Oocytes and Cumulus Cells after In Vitro Maturation. After in vitro maturation of COCs, oocytes and cumulus cells transcribe genes coding for enzymes involved in LPA synthesis (ATX and PLA2) as well as LPARs (Figures 1 and 2). We found significantly higher mRNA expression of LPAR2 than other three LPARs in bovine oocytes (Figure 1(a); $P<$ $0.05)$. The expression of all examined LPARs in the cumulus cells did not significantly differ (Figure 2(a); $P>0.05$ ). In the bovine oocytes the expression of ATX was higher than that of PLA2 (Figure 1(b); $P<0.05$ ), whereas in cumulus cells the opposite was observed (Figure 2(b); $P<0.05$ ).

\subsection{Effect of LPA on mRNA Abundance of Oocyte Quality} Markers and Genes Involved in Apoptosis in Oocytes and Cumulus Cells after In Vitro Maturation. We found higher mRNA abundance of FST and GDF9 in the oocytes from the LPA-stimulated group compared to oocytes from the control group (Figures 3(a) and 3(b); $P<0.05$ ). The supplementation of the maturation medium with LPA did not significantly influence BMP15 mRNA level in the examined oocytes (Figure 3(c); $P>0.05$ ). In the cumulus cells there was lower mRNA abundance of all examined CTSs from the LPA-stimulated group compared to cumulus cells from the 
TABLE 1: Primers used for real-time PCR.

\begin{tabular}{|c|c|c|c|}
\hline Gene & Primer sequence $\left(5^{\prime}-3^{\prime}\right)$ & Fragment size, bp & GenBank accession number \\
\hline \multirow{2}{*}{ LPAR1 } & ACGGAATCGGGATACCATGA & \multirow{2}{*}{86} & \multirow{2}{*}{ NM_174047.2 } \\
\hline & CCAGTCCAGGAGTCCAGCAG & & \\
\hline \multirow{2}{*}{$L P A R 2$} & TTCTATGTGAGGCGGCGAGT & \multirow{2}{*}{161} & \multirow{2}{*}{ NM_001192235.1 } \\
\hline & AGACCATCCAGGAGCAGCAC & & \\
\hline \multirow{2}{*}{$L P A R 3$} & TCCAACCTCATGGCCTTCTT & \multirow{2}{*}{101} & \multirow{2}{*}{ NM_001192741.2 } \\
\hline & GACCCACTCGTATGCGGAGA & & \\
\hline \multirow{2}{*}{ LPAR4 } & CCACAGTACCTCCAGAAAGTTCA & \multirow{2}{*}{192} & \multirow{2}{*}{ NM_001098105.1 } \\
\hline & TTGGAATTGGAAGTCAATGAATC & & \\
\hline \multirow{2}{*}{$A T X$} & 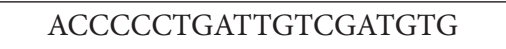 & \multirow{2}{*}{120} & \multirow{2}{*}{ NM_001080293.1 } \\
\hline & TCTCCGCATCTGTCCTTGGT & & \\
\hline \multirow{2}{*}{ PLA2 } & CTGCGTGCCACAAAAGTGAC & \multirow{2}{*}{92} & \multirow{2}{*}{ NM_001075864.1 } \\
\hline & TCGGGGGTTGAAGAGATGAA & & \\
\hline \multirow{2}{*}{ FST } & GCAGCTCTACATGCGTGGTG & \multirow{2}{*}{133} & \multirow{2}{*}{ NM_175801.2 } \\
\hline & TGACAGGCACTGGGGTAGGT & & \\
\hline \multirow{2}{*}{ GDF9 } & TCGGACATCGGTATGGCTCT & \multirow{2}{*}{86} & \multirow{2}{*}{ NM_174681.2 } \\
\hline & GGATGGTCTTGGCACTGAGG & & \\
\hline \multirow{2}{*}{$B M P 15$} & GCAGAGGAAGCCTCGGATCT & \multirow{2}{*}{104} & \multirow{2}{*}{ NM_001031752.1 } \\
\hline & CAATGGTGCGGTTTTCCCTA & & \\
\hline \multirow{2}{*}{ CTSB } & GGCTCACССТСТССАGTCСT & \multirow{2}{*}{136} & \multirow{2}{*}{ NM_174031.2 } \\
\hline & TCACAACCGCCTTGTCTGAA & & \\
\hline \multirow{2}{*}{ CTSK } & GAACCACTTGGGGGACATGA & 77 & NM 0010344351 \\
\hline & GGGAACGAGAAGCGGGTACT & $1 / 1$ & NM_001034435.1 \\
\hline CTSS & CCGCCGTCAGCATTCTTAGT & 99 & NM 001033 \\
\hline C1SO & CATGTGCCATTGCAGAGGAG & 99 & NIM_001033615.1 \\
\hline CTSZ & GGGGAGGGAGAAGATGATGG & 146 & NM 0010778351 \\
\hline & CCACGGAGACGATGTGGTTT & & \\
\hline$B C L 2$ & GAGTTCGGAGGGGTCATGTG & 203 & NM_001166486.1 \\
\hline & GCCTTCAGAGACAGCCAGGA & & \\
\hline$B A X$ & GTGCCCGAGTTGATCAGGAC & 126 & NM 1738941 \\
\hline & CCATGTGGGTGTCCCAAAGT & & \\
\hline$G A P D H$ & CACCCTCAAGATTGTCAGCA & 103 & NM 0010340342 \\
\hline ЧАРDП & GGTCATAAGTCCCTCCACGA & & \\
\hline
\end{tabular}

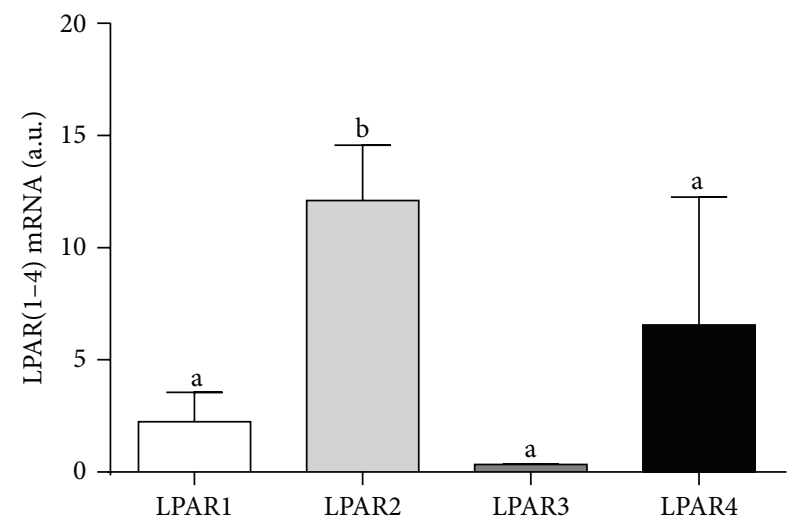

(a)

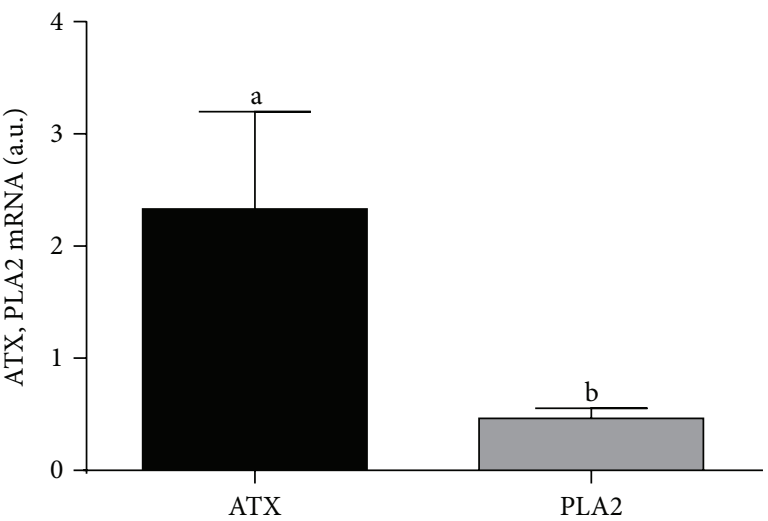

(b)

FIGURE 1: mRNA expression of (a) LPA receptors (LPAR1-4) and (b) autotaxin (ATX) and phospholipase A2 (PLA2) in oocytes. The values are expressed as mean \pm SEM. Different letters indicate significant differences $(P<0.05)$, as determined by one-way ANOVA and Student's $t$-test, respectively. 


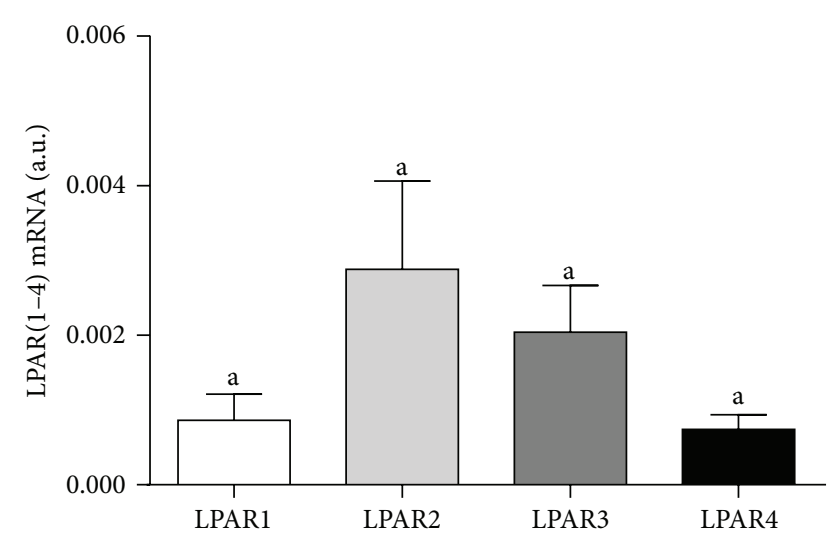

(a)

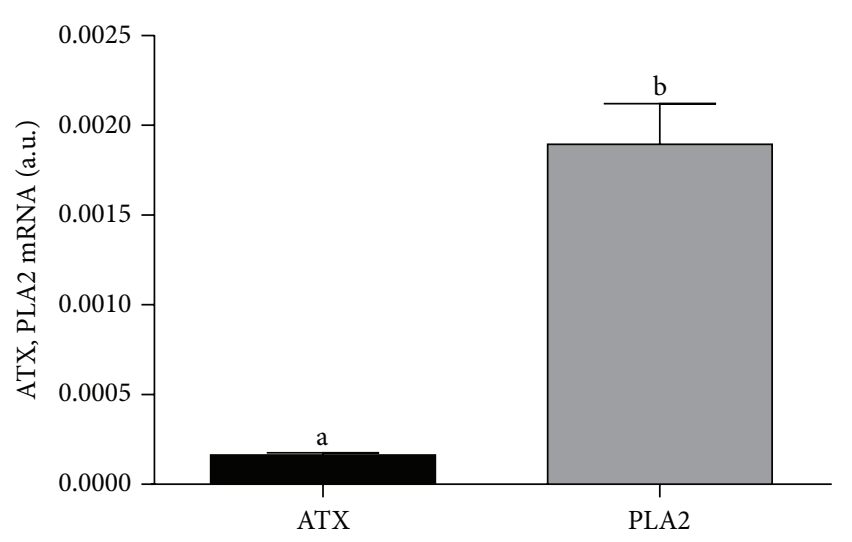

(b)

FIGURE 2: mRNA expression of (a) LPA receptors (LPAR1-4) and (b) autotaxin (ATX) and phospholipase A2 (PLA2) in cumulus cells. The values are expressed as mean \pm SEM. Different letters indicate significant differences $(P<0.05)$, as determined by one-way ANOVA and Student's $t$-test, respectively.

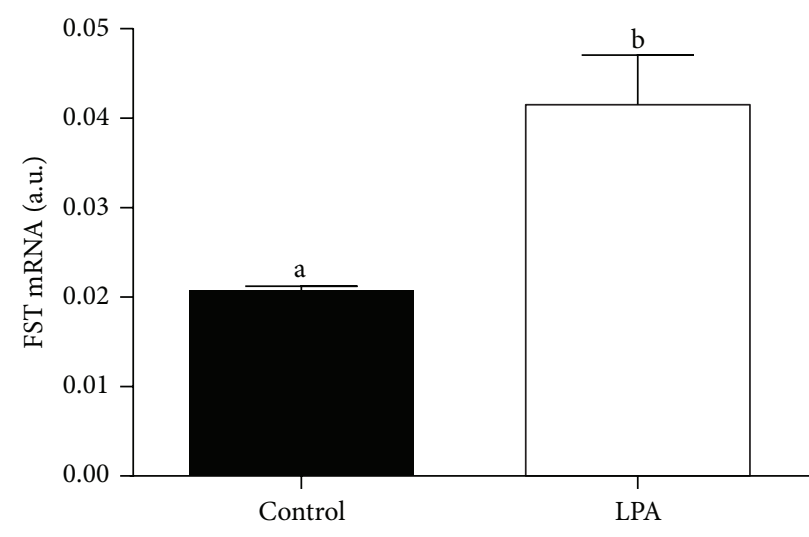

(a)

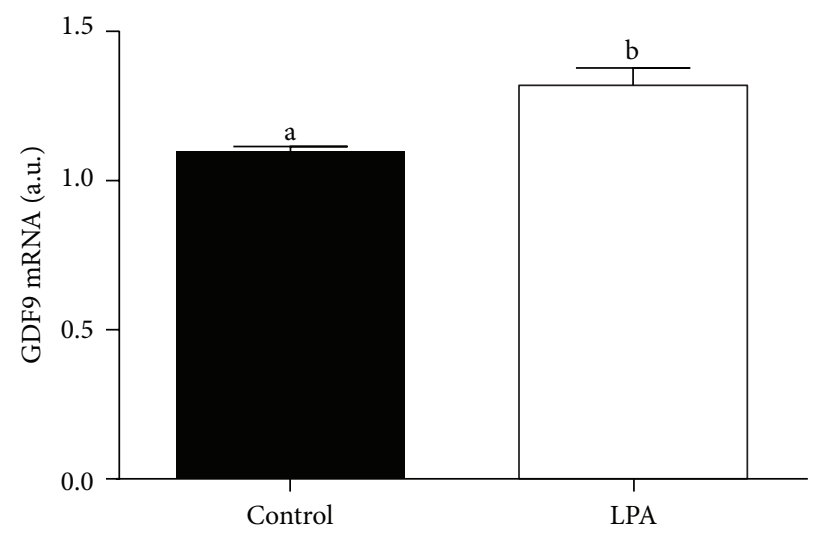

(b)

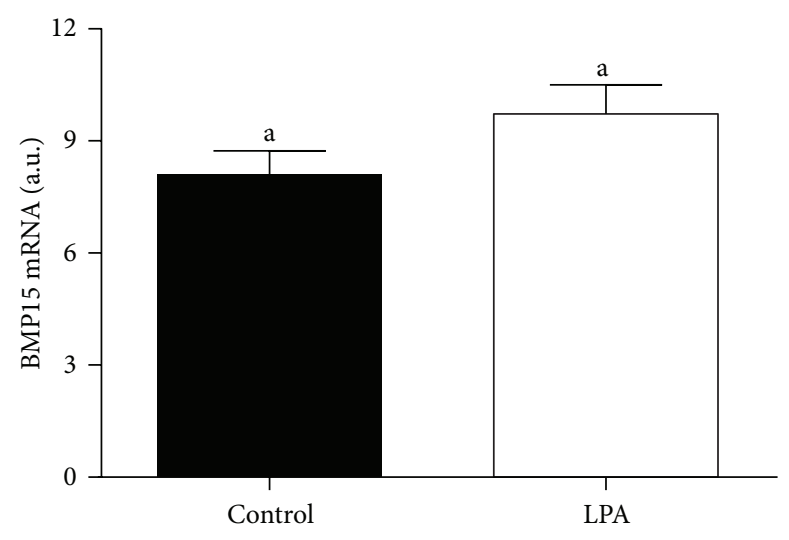

(c)

FIGURE 3: The effect of LPA $\left(10^{-5} \mathrm{M}\right)$ supplementation of maturation medium on mRNA abundance of FST (a), GDF9 (b), and BMP15 (c) in oocytes. The values are expressed as mean \pm SEM. Different letters indicate significant differences $(P<0.05)$, as determined by Student's $t$-test. 


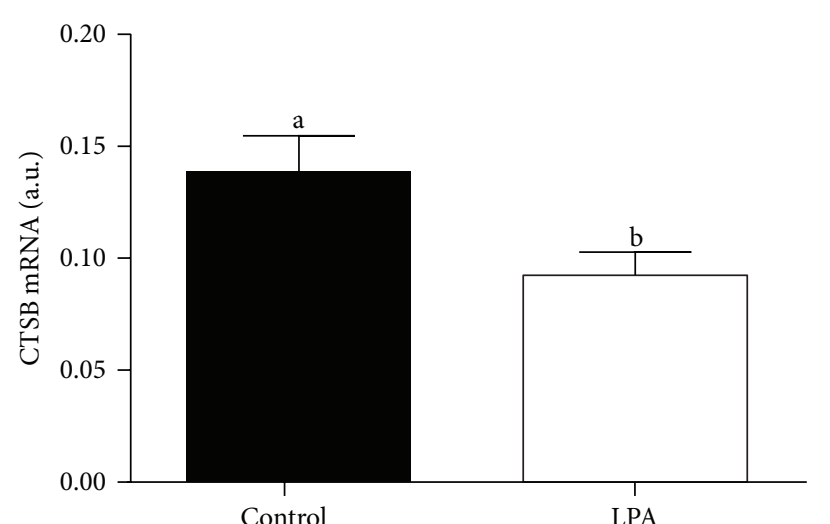

(a)

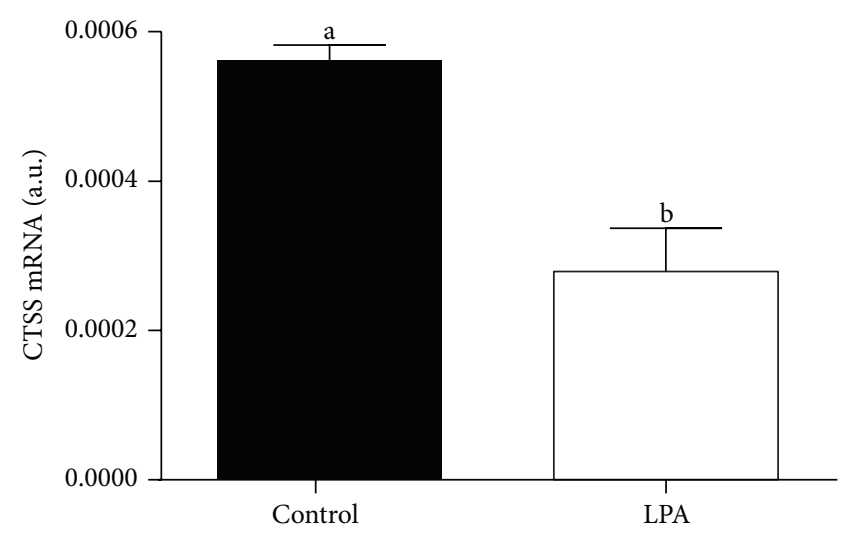

(c)

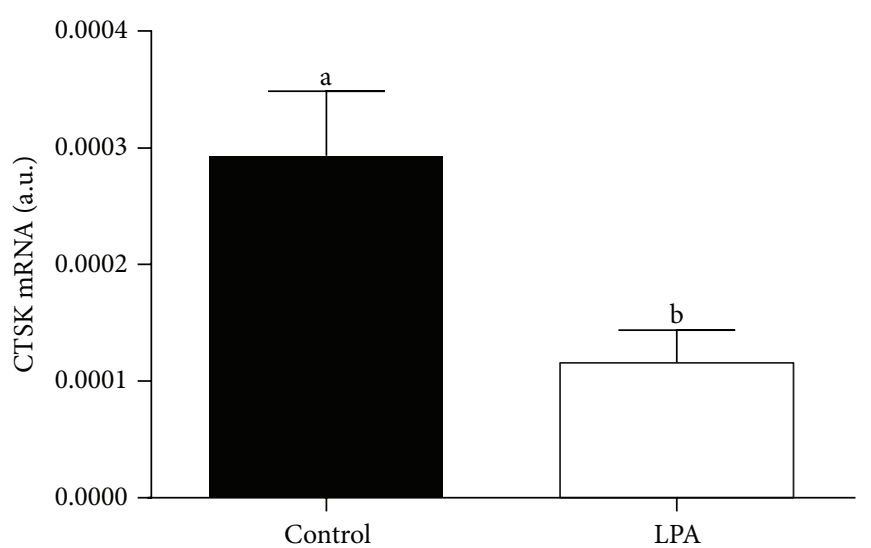

(b)

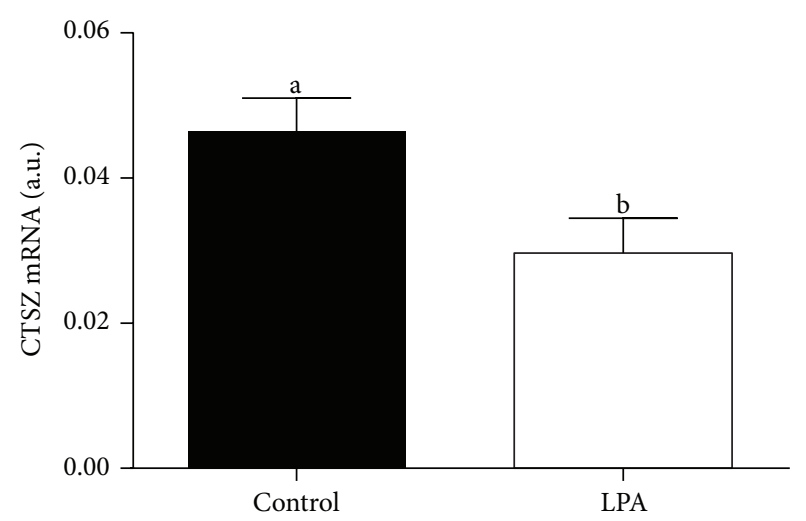

(d)

FIGURE 4: The effect of LPA $\left(10^{-5} \mathrm{M}\right)$ supplementation of maturation medium on mRNA abundance of CTSB (a), CTSK (b), CTSS (c), and CTSZ (d) in cumulus cells. The values are expressed as mean \pm SEM. Different letters indicate significant differences $(P<0.05)$, as determined by Student's $t$-test.

control group (Figure 4; $P<0.05$ ). We demonstrated higher $B C L 2$ and lower BAX mRNA level in the oocytes from the LPA-stimulated group compared to oocytes from the control group (Figures 5(a) and 5(b); $P<0.05)$. The BAX/BCL2 ratio was significantly lower in the oocytes matured in the presence of LPA compared to the oocytes from the control group (Figure 5(c); $P<0.05$ ). The supplementation of the maturation medium with LPA did not significantly influence mRNA level of $B C L 2$ and $B A X$ or $B A X / B C L 2$ ratio in the examined cumulus cells (Figure 6; $P>0.05$ ).

\subsection{Effect of LPA Supplementation of Maturation Medium on} Embryonic Development. As shown in Table 2, we did not find any significant differences in the cleavage rates on day 2 between the control group and the LPA-stimulated group (61.7\% versus $56.8 \%$, resp.; $P>0.05$ ). The blastocyst rates on day 7 were similar in the control group and the LPAstimulated group $(24.5 \%$ versus $28.4 \%$, resp.; $P>0.05)$.

\section{Discussion}

This study is the first to demonstrate mRNA expression of four types of LPARs and two main enzymes involved in LPA synthesis (ATX and PLA2) in bovine oocytes and cumulus cells. This indicates that bovine COCs are a potential source and target of LPA action and that LPA may be involved in cellular signaling between the oocyte and cumulus cells during maturation. Up to now, the presence of LPAR1 and LPAR2 was proposed only in the murine cumulus cells [35]. In mice it was also demonstrated that during blastocyst differentiation in vitro, embryos expressed LPAR1 mRNA constitutively, LPAR2 only in the late stage blastocysts, and there was no expression of LPAR3 [38]. However, van Meeteren et al. [39] demonstrated mRNA expression of four LPA receptors during murine embryonic development in vivo from E6.5 to E10.5 with significantly higher expression of $L P A R 1$ than that of LPAR2-4. In ruminants, Liszewska et al. [17] showed that LPAR1, LPAR2, and LPAR3 transcripts were expressed in ovine conceptuses during early pregnancy and postulated the main role of LPAR1 and LPAR3 at the time of implantation. In cows, we documented the presence of LPAR1 in the endometrium and four isoforms of LPARs in the CL with the dominant function of LPAR2 and LPAR4 $[19,20]$. Moreover, in bovine granulosa cells four types of LPARs were expressed with the highest transcript abundance of LPAR1 [21]. 


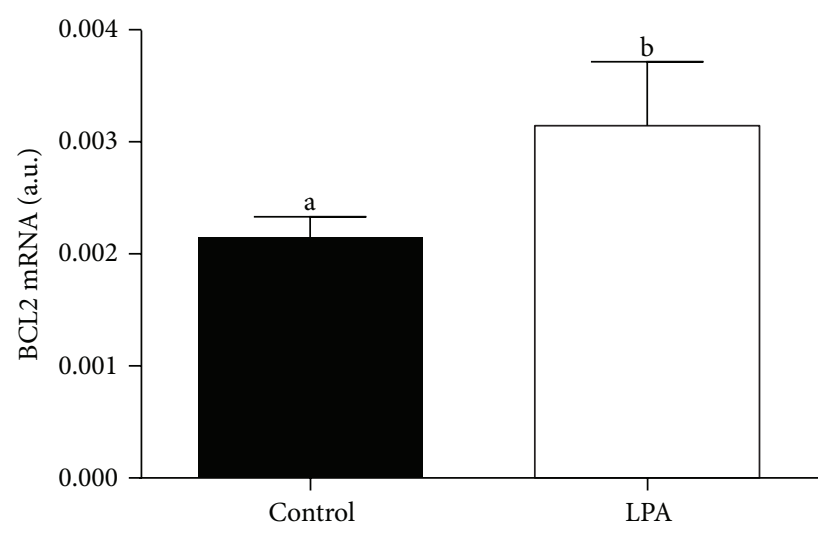

(a)

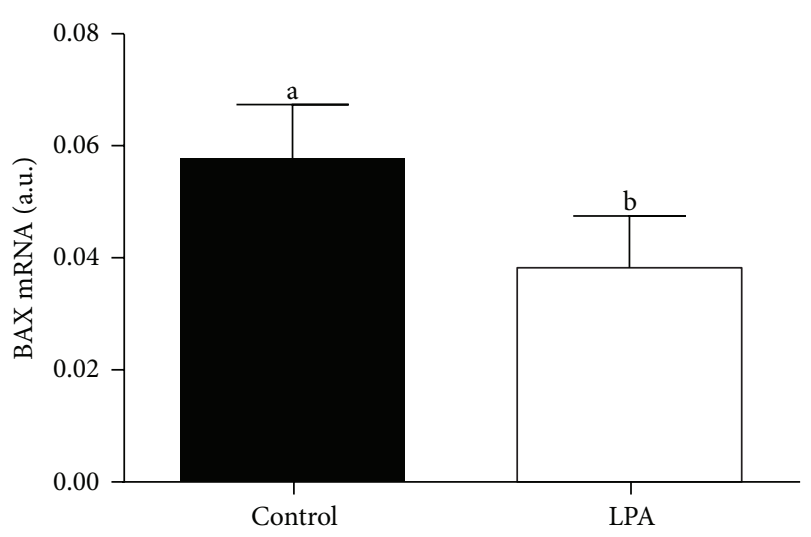

(b)

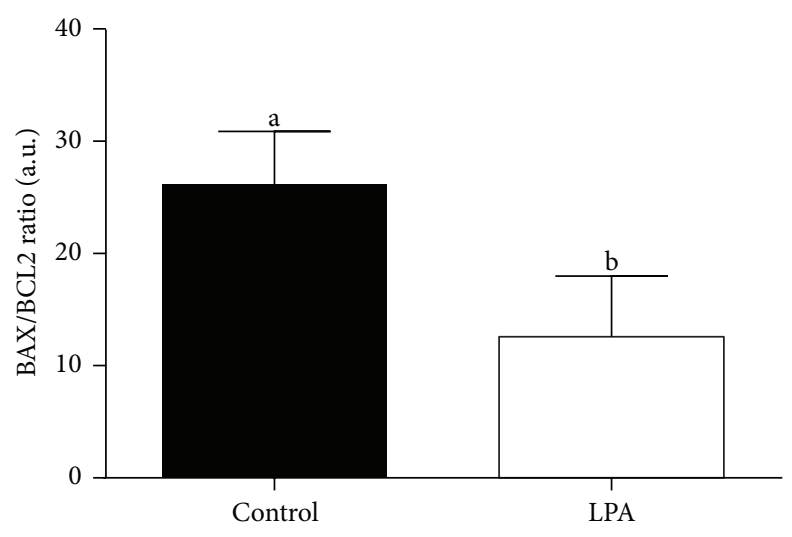

(c)

FIGURE 5: The effect of LPA $\left(10^{-5} \mathrm{M}\right)$ supplementation of maturation medium on mRNA abundance of $B C L 2$ (a), BAX (b), and BAX/BCL2 ratio $(c)$ in oocytes. The values are expressed as mean \pm SEM. Different letters indicate significant differences $(P<0.05)$, as determined by Student's $t$-test.

The transcript level of ATX mRNA was only identified during early embryo development in mouse and it was shown that the offspring of ATX-knockout mice died during embryonic development [39]. In sheep, Liszewska et al. [17] detected expression of ATX in embryonic trophectoderm from day 12 to day 16 of pregnancy. In our previous study, we demonstrated the presence of ATX and PLA2 in stromal and epithelial cells of the bovine endometrium as well as mRNA expression of ATX and PLA2 in granulosa cells [21, 40].

Considering that there is the possibility of LPA synthesis and action during in vitro maturation of COCs, in the second part of our study we examined the effect of LPA supplementation of maturation medium on mRNA abundance of the oocyte quality markers in oocytes and cumulus cells obtained after in vitro maturation. Supplementation of maturation medium with LPA increased oocyte GDF9 and FST transcripts, whereas BMP15 mRNA abundance was not affected. Morphological quality of oocytes can be depicted from the number and compactness of the neighboring cumulus cell layers [41]. Oocytes are responsible for cumulus cell expansion [42, 43], regulate steroid production [43-45], and maintain cumulus cell phenotype [45]. This is accomplished through the paracrine secretion of factors, which include TGF- $\beta$ superfamily members, notably GDF9 and BMP15, also known as GDF-9B [46-48]. In cow, BMP15 and GDF9 transcription occur in oocyte during processes of in vitro maturation and fertilization and in preimplantation embryos until the five- to eight-cell or morula stage as well as in high quality oocytes [49-51]. Therefore, BMP15 and GDF9 are considered valid oocyte quality marker genes [5052]. Moreover, Gendelman et al. [50] found that mRNA expression of GDF9 was higher in early- versus late-cleaved embryos. Gendelman and Roth [51] documented higher GDF9 transcript level in matured oocytes collected in the cold season than in those from the hot season and postulated that seasonally induced alterations in GDF9 expression were involved in the reduced developmental competence noted for oocytes collected in the hot season. In fact, addition of BMP15 and GDF9 to maturation medium enhanced oocyte developmental competence in the cow [52]. Oocyte mRNA abundance of FST was associated with time of the first cleavage that accounted for high developmental competence of the oocyte [53]. Moreover, Lee et al. [54] showed higher level of FST protein in early versus late cleaving two-cell 


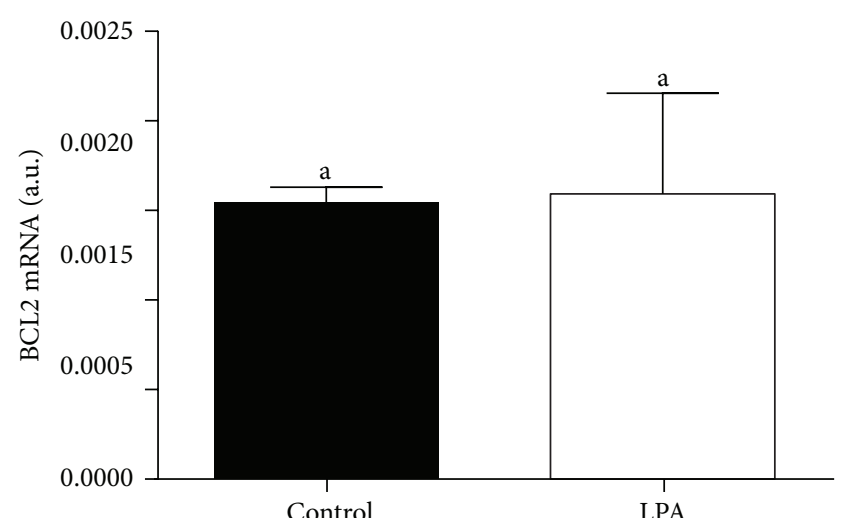

(a)

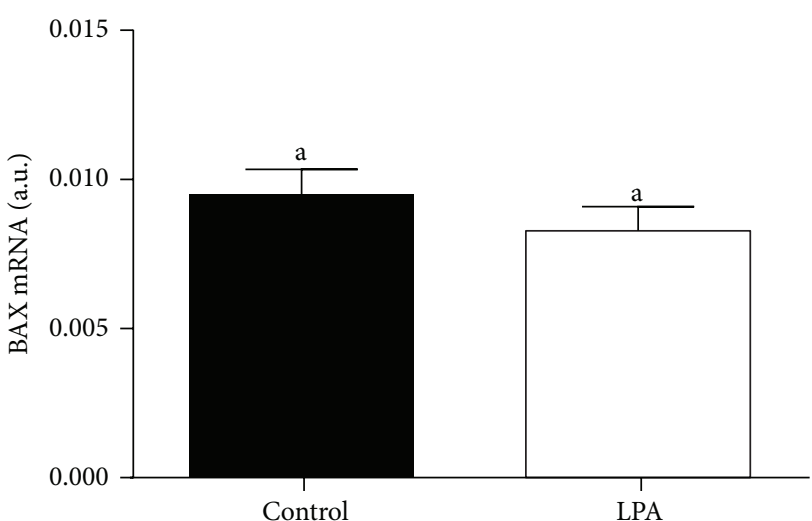

(b)

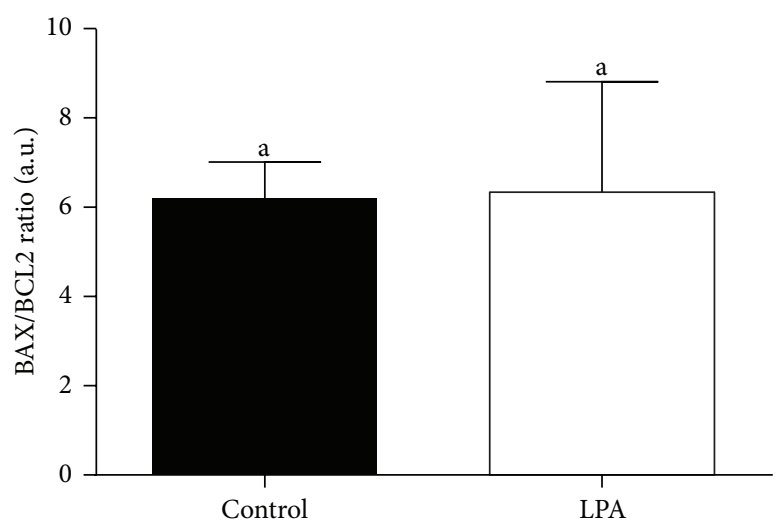

(c)

FIGURE 6: The effect of LPA $\left(10^{-5} \mathrm{M}\right)$ supplementation of maturation medium on mRNA abundance of $B C L 2$ (a), BAX (b), and $B A X / B C L 2$ ratio (c) in cumulus cells. The values are expressed as mean \pm SEM. Different letters indicate significant differences $(P<0.05)$, as determined by Student's $t$-test.

TABLE 2: The effect of LPA supplementation of in vitro maturation medium on cleavage and blastocyst rates on day 2 and day 7 , respectively.

\begin{tabular}{lccccc}
\hline Supplement & Matured oocytes, $n$ & Cleaved embryos, $n$ & Cleavage rate, $\%$ & Blastocyst on day $7, n$ & Blastocyst rate, $\%$ \\
\hline Control (PBS) & 188 & 116 & 61,7 & 46 & 24,5 \\
LPA $\left(10^{-5} \mathrm{M}\right)$ & 190 & 108 & 56,8 & 54 & 28,4 \\
\hline
\end{tabular}

Proportion of cleaved embryos and of blastocysts relative to the total number of matured oocytes.

embryos and the stimulatory effects of FST on time to first cleavage, blastocyst rate, and cell allocation within the blastocyst. Here, increased transcription levels of GDF9 and FST following LPA supplementation during in vitro maturation may indicate that LPA increased oocyte competence.

The role of cumulus cells during in vitro maturation is vital for oocyte maturation and subsequent fertilization and embryo development $[55,56]$. Cumulus cells play a pivotal role in the provision of nutrients to the oocyte $[57,58]$ as well as stimulate oocyte glutathione synthesis [59]. Therefore, gene expression in cumulus cells may also reflect oocyte quality and competence. Bettegowda et al. [60] demonstrated negative correlation between CTSs transcript abundance in cumulus cells and oocyte quality as well as their developmental competence. Here, LPA supplementation of maturation medium decreased cumulus cell transcript levels of CTSB, CTSK, CTSS, and CTSZ. Again, this may indicate that LPA increased oocyte competence.

LPA supplementation of maturation medium had no effect on transcription levels of proapoptotic $(B A X)$ and antiapoptotic (BCL2) genes in cumulus cells but decreased oocyte $B A X$ mRNA abundance and increased oocyte BCL2 transcript levels. Moreover, the $B A X / B C L 2$ ratio was lower in the oocytes matured in the presence of LPA compared to the oocytes from the control group. Apoptosis in cumulus cells may be also a good marker of oocyte developmental competence [61] due to the bidirectional communication between oocytes and cumulus cells [62]. Cumulus cells regulate nuclear and cytoplasmic maturation of oocytes and prevent apoptosis induced by oxidative stress during in vitro maturation $[63,64]$. However, the relationship between the occurrence of apoptosis in cumulus cells and oocyte 
developmental competence is controversial [65-69]. In fact, some studies report that oocytes with early signs of atresia are developmentally more competent $[70,71]$. Oocytes with the highest transcriptional level of $B A X$ and the lowest mRNA level of BCL2 exhibited the highest nuclear maturation, cleavage, and blastocyst rate [71]. In contrast, in other studies, good quality oocytes showed the highest transcription levels of BCL2 and the lowest mRNA abundance of $B A X$ [72]. The ratio of $B C L 2$ to $B A X$ may be an indicator of the tendency of oocytes and embryos towards either survival or apoptosis [72]. According to Yuan et al. [73] COCs with no signs of atresia yield higher blastocyst rates. The authors found that the degree of apoptosis in the cumulus cells is negatively correlated to the developmental competence of oocyte [73]. On the other hand, another group of authors demonstrated that the level of apoptosis in cumulus cells does not correlate either with COC morphology or oocyte meiotic stage [74]. Here, LPA decreased $B A X / B C L 2$ ratio, indicating that an antiapoptotic balance was induced in the oocyte, which may be relevant for oocyte competence. Hussein et al. [75] showed that, at the beginning, the apoptotic signal appears in the cumulus cells and then in the oocyte. Similarly, we have detected an antiapoptotic effect of LPA in cultured luteal cells: LPA inhibited the stimulatory effects of tumor necrosis factor alpha $(\mathrm{TNF} \alpha)$ and interferon gamma (IFN $\gamma)$ on the expression of BAX mRNA and protein in steroidogenic luteal cells [76].

Although, LPA supplementation of maturation medium promoted transcription of quality marker genes in oocytes, decreased transcription of CTSs in cumulus cells, and induced and antiapoptotic balance in oocytes, this was not translated into a higher number of cleaved embryos and subsequent blastocyst development. Ye et al. [77] examined the influence of LPA on the embryo implantation in LPA3 receptor null mice. According to these authors, examined mice exhibited delayed implantation, reduced number of implantation sites, delayed embryonic development, and increased embryonic mortality [77]. However, we did not examine the effect of LPA on the implantation of bovine embryos. Moreover, we cannot exclude that LPA supplementation of maturation medium can impact the maturation process itself and/or early pronuclear stages of embryo development. In rodents, LPA promoted nuclear and cytoplasmic oocyte maturation via cumulus cells and through the closure or loosening of gap junctions between cumulus cells and the oocyte $[35,36]$, as well as stimulated blastocyst development $[38,78,79]$. Differences in early embryonic development between the mouse and bovine models may account for the discrepancy in the rate of blastocyst development observed in our study and in the studies with rodents. Further studies are needed to evaluate the role of LPA stimulation during in vitro maturation and embryo culture in in vivo survival of bovine embryos.

In conclusion, our study demonstrates for the first time that bovine COCs (both oocytes and cumulus cells) are a potential source and target of LPA action. We postulate that LPA exerts an autocrine and/or paracrine signaling, through several LPARs, between the oocyte and cumulus cells. LPA supplementation of maturation medium increases oocyte transcripts of quality marker genes (FST and GDF9), promotes an antiapoptotic balance in transcription of genes involved in apoptosis (BCL2 and BAX), and decreases cumulus cells transcripts associated with low viability (CTSs). These effects, although not affecting in vitro development until the blastocyst stage, may be of relevance for subsequent in vivo developmental competence.

\section{Disclosure}

The data presented in the manuscript are the part of $\mathrm{PhD}$ Thesis of Dorota Boruszewska.

\section{Conflict of Interests}

The authors declare that there is no conflict of interests regarding the publication of this paper.

\section{Authors' Contribution}

Dorota Boruszewska and Ana Catarina Torres contributed equally to this work.

\section{Acknowledgments}

This research was supported by Grants-in-Aid for Scientific Research from the Polish National Science Centre (2012/05/E/NZ9/03480). This research was founded by a Grant from the Foundation for Science and Technology PTDC/CVT/65690/2006. Dorota Boruszewska and Ilona Kowalczyk-Zieba were supported by the European Union within the European Social Fund (DrINNO3).

\section{References}

[1] X. Ye and J. Chun, "Lysophosphatidic acid (LPA) signaling in vertebrate reproduction," Trends in Endocrinology and Metabolism, vol. 21, no. 1, pp. 17-24, 2010.

[2] E. J. Goetzl, H. Dolezalova, Y. Kong et al., "Distinctive expression and functions of the type 4 endothelial differentiation gene-encoded $\mathrm{G}$ protein-coupled receptor for lysophosphatidic acid in ovarian cancer," Cancer Research, vol. 59, no. 20, pp. 5370-5375, 1999.

[3] T. C. Spohr, J. W. Choi, S. E. Gardell et al., "Lysophosphatidic acid receptor-dependent secondary effects via astrocytes promote neuronal differentiation," The Journal of Biological Chemistry, vol. 283, no. 12, pp. 7470-7479, 2008.

[4] J. A. Weiner and J. Chun, "Schwann cell survival mediated by the signaling phospholipid lysophosphatidic acid," Proceedings of the National Academy of Sciences of the United States of America, vol. 96, no. 9, pp. 5233-5238, 1999.

[5] X. Ye, M. K. Skinner, G. Kennedy, and J. Chun, "Age-dependent loss of sperm production in mice via impaired lysophosphatidic acid signaling," Biology of Reproduction, vol. 79, no. 2, pp. 328336, 2008.

[6] V. Härmä, M. Knuuttila, J. Virtanen et al., "Lysophosphatidic acid and sphingosine-1-phosphate promote morphogenesis and block invasion of prostate cancer cells in three-dimensional organotypic models," Oncogene, vol. 31, no. 16, pp. 2075-2089, 2012. 
[7] M.-C. Huang, H.-Y. Lee, C.-C. Yeh, Y. Kong, C. J. Zaloudek, and E. J. Goetzl, "Induction of protein growth factor systems in the ovaries of transgenic mice overexpressing human type 2 lysophosphatidic acid G protein-coupled receptor (LPA2)," Oncogene, vol. 23, no. 1, pp. 122-129, 2004.

[8] J. Aoki, "Mechanisms of lysophosphatidic acid production," Seminars in Cell and Developmental Biology, vol. 15, no. 5, pp. 477-489, 2004.

[9] K. Nakamura, T. Kishimoto, R. Ohkawa et al., "Suppression of lysophosphatidic acid and lysophosphatidylcholine formation in the plasma in vitro: proposal of a plasma sample preparation method for laboratory testing of these lipids," Analytical Biochemistry, vol. 367, no. 1, pp. 20-27, 2007.

[10] K. Bandoh, J. Aoki, H. Hosono et al., "Molecular cloning and characterization of a novel human G-protein- coupled receptor, EDG7, for lysophosphatidic acid," The Journal of Biological Chemistry, vol. 274, no. 39, pp. 27776-27785, 1999.

[11] D.-S. Im, C. E. Heise, M. A. Harding et al., "Molecular cloning and characterization of a lysophosphatidic acid receptor, Edg-7, expressed in prostate," Molecular Pharmacology, vol. 57, no. 4, pp. 753-759, 2000.

[12] K. Noguchi, S. Ishii, and T. Shimizu, "Identification of p2y9/GPR23 as a novel $G$ protein-coupled receptor for lysophosphatidic acid, structurally distant from the Edg family," The Journal of Biological Chemistry, vol. 278, no. 28, pp. 2560025606, 2003.

[13] J. Aoki, A. Inoue, and S. Okudaira, "Two pathways for lysophosphatidic acid production," Biochimica et Biophysica Acta, vol. 1781, no. 9, pp. 513-518, 2008.

[14] T. M. McIntyre, A. V. Pontsler, A. R. Silva et al., "Identification of an intracellular receptor for lysophosphatidic acid (LPA): LPA is a transcellular PPAR $\gamma$ agonist," Proceedings of the National Academy of Sciences of the United States of America, vol. 100, no. 1, pp. 131-136, 2003.

[15] S. Okudaira, H. Yukiura, and J. Aoki, "Biological roles of lysophosphatidic acid signaling through its production by autotaxin," Biochimie, vol. 92, no. 6, pp. 698-706, 2010.

[16] A. A. Jarvis, C. Cain, and E. A. Dennis, "Purification and characterization of a lysophospholipase from human amnionic membranes," The Journal of Biological Chemistry, vol. 259, no. 24, pp. 15188-15195, 1984.

[17] E. Liszewska, P. Reinaud, E. Billon-Denis, O. Dubois, P. Robin, and G. Charpigny, "Lysophosphatidic acid signaling during embryo development in sheep: involvement in prostaglandin synthesis," Endocrinology, vol. 150, no. 1, pp. 422-434, 2009.

[18] I. Woclawek-Potocka, I. Kowalczyk-Zieba, and D. J. Skarzynski, "Lysophosphatidic acid action during early pregnancy in the cow: in vivo and in vitro studies," The Journal of Reproduction and Development, vol. 56, no. 4, pp. 411-420, 2010.

[19] I. Woclawek-Potocka, J. Komiyama, J. S. Saulnier-Blache et al., "Lysophosphatic acid modulates prostaglandin secretion in the bovine uterus," Reproduction, vol. 137, no. 1, pp. 95-105, 2009.

[20] I. Kowalczyk-Zieba, D. Boruszewska, J. S. Saulnier-Blache et al., "Lysophosphatidic acid action in the bovine corpus luteum-an in vitro study," The Journal of Reproduction and Development, vol. 58, no. 6, pp. 661-671, 2012.

[21] D. Boruszewska, E. Sinderewicz, I. Kowalczyk-Zieba, D. J. Skarzynski, and I. Woclawek-Potocka, "Influence of lysophosphatidic acid on estradiol production and follicle stimulating hormone action in bovine granulosa cells," Reproductive Biology, vol. 13, no. 4, pp. 344-347, 2013.
[22] I. Woclawek-Potocka, K. Kondraciuk, and D. J. Skarzynski, "Lysophosphatidic acid stimulates prostaglandin E2 production in cultured stromal endometrial cells through LPA1 receptor," Experimental Biology and Medicine, vol. 234, no. 8, pp. 986-993, 2009.

[23] R. A. Sorensen and P. M. Wassarman, "Relationship between growth and meiotic maturation of the mouse oocyte," Developmental Biology, vol. 50, no. 2, pp. 531-536, 1976.

[24] D. Wickramasinghe, K. M. Ebert, and D. F. Albertini, "Meiotic competence acquisition is associated with the appearance of Mphase characteristics in growing mouse oocytes," Developmental Biology, vol. 143, no. 1, pp. 162-172, 1991.

[25] J. J. Eppig, R. M. Schultz, M. O’Brien, and F. Chesnel, "Relationship between the developmental programs controlling nuclear and cytoplasmic maturation of mouse oocytes," Developmental Biology, vol. 164, no. 1, pp. 1-9, 1994.

[26] C. Payne and G. Schatten, "Golgi dynamics during meiosis are distinct from mitosis and are coupled to endoplasmic reticulum dynamics until fertilization," Developmental Biology, vol. 264, no. 1, pp. 50-63, 2003.

[27] H. Torner, K.-P. Brüssow, H. Alm et al., "Mitochondrial aggregation patterns and activity in porcine oocytes and apoptosis in surrounding cumulus cells depends on the stage of preovulatory maturation," Theriogenology, vol. 61, no. 9, pp. 16751689, 2004.

[28] C. de Vantéry, A. C. Gavin, J. D. Vassalli, and S. SchorderetSlatkine, "An accumulation of $\mathrm{p} 34 \mathrm{cdc} 2$ at the end of mouse oocyte growth correlates with the acquisition of meiotic competence," Developmental Biology, vol. 174, no. 2, pp. 335-344, 1996.

[29] C. Krischek and B. Meinecke, "In vitro maturation of bovine oocytes requires polyadenylation of mRNAs coding proteins for chromatin condensation, spindle assembly, MPF and MAP kinase activation," Animal Reproduction Science, vol. 73, no. 3-4, pp. 129-140, 2002.

[30] M. J. Carabatsos, C. Sellitto, D. A. Goodenough, and D. F. Albertini, "Oocyte-granulosa cell heterologous gap junctions are required for the coordination of nuclear and cytoplasmic meiotic competence," Developmental Biology, vol. 226, no. 2, pp. 167-179, 2000.

[31] R. de La Fuente and J. J. Eppig, “Transcriptional activity of the mouse oocyte genome: companion granulosa cells modulate transcription and chromatin remodeling," Developmental Biology, vol. 229, no. 1, pp. 224-236, 2001.

[32] K. Reynaud, R. Cortvrindt, J. Smitz, and M. A. Driancourt, "Effects of Kit Ligand and anti-Kit antibody on growth of cultured mouse preantral follicles," Molecular Reproduction and Development, vol. 56, no. 4, pp. 483-494, 2000.

[33] A. Torres, M. Batista, P. Diniz, L. Mateus, and L. Lopes-daCosta, "Embryo-luteal cells co-culture: an in vitro model to evaluate steroidogenic and prostanoid bovine early embryomaternal interactions," In Vitro Cellular \& Developmental Biology, vol. 49, no. 2, pp. 134-146, 2013.

[34] A. Tokumura, M. Miyake, Y. Nishioka, S. Yamano, T. Aono, and K. Fukuzawa, "Production of lysophosphatidic acids by lysophospholipase D in human follicular fluids of in vitro fertilization patients," Biology of Reproduction, vol. 61, no. 1, pp. 195-199, 1999.

[35] J. Komatsu, S. Yamano, A. Kuwahara, A. Tokumura, and M. Irahara, "The signaling pathways linking to lysophosphatidic acid-promoted meiotic maturation in mice," Life Sciences, vol. 79, no. 5, pp. 506-511, 2006. 
[36] K. Hinokio, S. Yamano, K. Nakagawa et al., "Lysophosphatidic acid stimulates nuclear and cytoplasmic maturation of golden hamster immature oocytes in vitro via cumulus cells," Life Sciences, vol. 70, no. 7, pp. 759-767, 2002.

[37] P. Holm, P. J. Booth, M. H. Schmidt, T. Greve, and H. Callesen, "High bovine blastocyst development in a static in vitro production system using SOFaa medium supplemented with sodium citrate and myo-inositol with or without serumproteins," Theriogenology, vol. 52, no. 4, pp. 683-700, 1999.

[38] Z. Liu and D. R. Armant, "Lysophosphatidic acid regulates murine blastocyst development by transactivation of receptors for heparin-binding EGF-like growth factor," Experimental Cell Research, vol. 296, no. 2, pp. 317-326, 2004.

[39] L. A. van Meeteren, P. Ruurs, C. Stortelers et al., "Autotaxin, a secreted lysophospholipase D, is essential for blood vessel formation during development," Molecular and Cellular Biology, vol. 26, no. 13, pp. 5015-5022, 2006.

[40] D. Boruszewska, I. Kowalczyk-Zieba, K. Piotrowska-Tomala et al., "Which bovine endometrial cells are source and target for lysophosphatidic acid?" Reproductive Biology, vol. 13, no. 1, pp. 100-103, 2013.

[41] H. A. Amer, A.-R. O. Hegab, and S. M. Zaabal, "Some studies on the morphological aspects of buffalo oocytes in relation to the ovarian morphology and culture condition," In Vitro Cellular \& Developmental Biology, 2009.

[42] R. Buccione, B. C. Vanderhyden, P. J. Caron, and J. J. Eppig, "FSH-induced expansion of the mouse cumulus oophorus in vitro is dependent upon a specific factor(s) secreted by the oocyte," Developmental Biology, vol. 138, no. 1, pp. 16-25, 1990.

[43] J. A. Elvin, A. T. Clark, P. Wang, N. M. Wolfman, and M. M. Matzuk, "Paracrine actions of growth differentiation factor-9 in the mammalian ovary," Molecular Endocrinology, vol. 13, no. 6, pp. 1035-1048, 1999.

[44] B. C. Vanderhyden and A. M. Tonary, "Differential regulation of progesterone and estradiol production by mouse cumulus and mural granulosa cells by a factor(s) secreted by the oocyte," Biology of Reproduction, vol. 53, no. 6, pp. 1243-1250, 1995.

[45] R. Li, R. J. Norman, D. T. Armstrong, and R. B. Gilchrist, "Oocyte-secreted factor(s) determine functional differences between bovine mural granulosa cells and cumulus cells," Biology of Reproduction, vol. 63, no. 3, pp. 839-845, 2000.

[46] M. J. Carabatsos, J. Elvin, M. M. Matzuk, and D. F. Albertini, "Characterization of oocyte and follicle development in growth differentiation factor-9-deficient mice," Developmental Biology, vol. 204, no. 2, pp. 373-384, 1998.

[47] F. Otsuka, Z. Yao, T.-H. Lee, S. Yamamoto, G. F. Erickson, and S. Shimasaki, "Bone morphogenetic protein-15: identification of target cells and biological functions," The Journal of Biological Chemistry, vol. 275, no. 50, pp. 39523-39528, 2000.

[48] J. L. Juengel, N. L. Hudson, D. A. Heath et al., "Growth differentiation factor 9 and bone morphogenetic protein 15 are essential for ovarian follicular development in sheep," Biology of Reproduction, vol. 67, no. 6, pp. 1777-1789, 2002.

[49] S. Pennetier, S. Uzbekova, C. Perreau, P. Papillier, P. Mermillod, and R. Dalbiès-Tran, "Spatio-temporal expression of the germ cell marker genes MATER, ZAR1, GDF9, BMP15, and VASA in adult bovine tissues, oocytes, and preimplantation embryos," Biology of Reproduction, vol. 71, no. 4, pp. 1359-1366, 2004.

[50] M. Gendelman, A. Aroyo, S. Yavin, and Z. Roth, "Seasonal effects on gene expression, cleavage timing, and developmental competence of bovine preimplantation embryos," Reproduction, vol. 140, no. 1, pp. 73-82, 2010.
[51] M. Gendelman and Z. Roth, "In vivo vs. in vitro models for studying the effects of elevated temperature on the GVstage oocyte, subsequent developmental competence and gene expression," Animal Reproduction Science, vol. 134, no. 3, pp. 125-134, 2012.

[52] T. S. Hussein, J. G. Thompson, and R. B. Gilchrist, "Oocytesecreted factors enhance oocyte developmental competence," Developmental Biology, vol. 296, no. 2, pp. 514-521, 2006.

[53] O. V. Patel, A. Bettegowda, J. J. Ireland, P. M. Coussens, P. Lonergan, and G. W. Smith, "Functional genomics studies of oocyte competence: evidence that reduced trascript abundance for follistatin is associated with poor developmental competence of bovine oocytes," Reproduction, vol. 133, no. 1, pp. 95106, 2007.

[54] K.-B. Lee, A. Bettegowda, G. Wee, J. J. Ireland, and G. W. Smith, "Molecular determinants of oocyte competence: potential functional role for maternal (oocyte-derived) follistatin in promoting bovine early embryogenesis," Endocrinology, vol. 150, no. 5, pp. 2463-2471, 2009.

[55] Y. Fukui and Y. Sakuma, "Maturation of bovine oocytes cultured in vitro: relation to ovarian activity, follicular size and the presence or absence of cumulus cells," Biology of Reproduction, vol. 22, no. 3, pp. 669-673, 1980.

[56] A. N. Fatehi, E. C. Zeinstra, R. V. Kooij, B. Colenbrander, and M. M. Bevers, "Effect of cumulus cell removal of in vitro matured bovine oocytes prior to in vitro fertilization on subsequent cleavage rate," Theriogenology, vol. 57, no. 4, pp. 1347-1355, 2002.

[57] M. L. Sutton-McDowall, R. B. Gilchrist, and J. G. Thompson, "Cumulus expansion and glucose utilisation by bovine cumulus-oocyte complexes during in vitro maturation: the influence of glucosamine and follicle-stimulating hormone," Reproduction, vol. 128, no. 3, pp. 313-319, 2004.

[58] K. A. Preis, G. Seidel Jr., and D. K. Gardner, "Metabolic markers of developmental competence for in vitro-matured mouse oocytes," Reproduction, vol. 130, no. 4, pp. 475-483, 2005.

[59] D. G. de Matos, C. C. Furnus, and D. F. Moses, "Glutathione synthesis during in vitro maturation of bovine oocytes: role of cumulus cells," Biology of Reproduction, vol. 57, no. 6, pp. 1420$1425,1997$.

[60] A. Bettegowda, O. V. Patel, K.-B. Lee et al., "Identification of novel bovine cumulus cell molecular markers predictive of oocyte competence: functional and diagnostic implications," Biology of Reproduction, vol. 79, no. 2, pp. 301-309, 2008.

[61] C. M. Corn, C. Hauser-Kronberger, M. Moser, G. Tews, and T. Ebner, "Predictive value of cumulus cell apoptosis with regard to blastocyst development of corresponding gametes," Fertility and Sterility, vol. 84, no. 3, pp. 627-633, 2005.

[62] F. de Loos, P. Kastrop, P. van Maurik, T. H. van Beneden, and T. A. Kruip, "Heterologous cell contacts and metabolic coupling in bovine cumulus oocyte complexes," Molecular Reproduction and Development, vol. 28, no. 3, pp. 255-259, 1991.

[63] S. Tanghe, A. van Soom, H. Nauwynck, M. Coryn, and A. de Kruif, "Minireview: functions of the cumulus oophorus during oocyte maturation, ovulation, and fertilization," Molecular Reproduction and Development, vol. 61, no. 3, pp. 414-424, 2002.

[64] H. Tatemoto, N. Sakurai, and N. Muto, "Protection of porcine oocytes against apoptotic cell death caused by oxidative stress during in vitro maturation: role of cumulus cells," Biology of Reproduction, vol. 63, no. 3, pp. 805-810, 2000.

[65] A. L. Mikkelsen, E. Høst, and S. Lindenberg, "Incidence of apoptosis in granulosa cells from immature human follicles," Reproduction, vol. 122, no. 3, pp. 481-486, 2001. 
[66] S. Kölle, M. Stojkovic, G. Boie, E. Wolf, and F. Sinowatz, "Growth hormone-related effects on apoptosis, mitosis, and expression of connexin 43 in bovine in vitro maturation cumulus-oocyte complexes," Biology of Reproduction, vol. 68, no. 5, pp. 1584-1589, 2003.

[67] M. Szołtys, Z. Tabarowski, and A. Pawlik, "Apoptosis of postovulatory cumulus granulosa cells of the rat," Anatomy and Embryology, vol. 202, no. 6, pp. 523-529, 2000.

[68] N. Manabe, Y. Imai, H. Ohno, Y. Takahagi, M. Sugimoto, and H. Miyamoto, "Apoptosis occurs in granulosa cells but not cumulus cells in the atretic antral follicles in pig ovaries," Experientia, vol. 52, no. 7, pp. 647-651, 1996.

[69] M. Y. Yang and R. Rajamahendran, "Morphological and biochemical identification of apoptosis in small, medium, and large bovine follicles and the effects of follicle-stimulating hormone and insulin-like growth factor-I on spontaneous apoptosis in cultured bovine granulosa cells," Biology of Reproduction, vol. 62, no. 5, pp. 1209-1217, 2000.

[70] S. Bilodeau-Goeseels and P. Panich, "Effects of oocyte quality on development and transcriptional activity in early bovine embryos," Animal Reproduction Science, vol. 71, no. 3-4, pp. 143$155,2002$.

[71] H. J. Li, D. J. Liu, M. Cang et al., "Early apoptosis is associated with improved developmental potential in bovine oocytes," Animal Reproduction Science, vol. 114, no. 1-3, pp. 89-98, 2009.

[72] M. Y. Yang and R. Rajamahendran, "Expression of Bcl-2 and Bax proteins in relation to quality of bovine oocytes and embryos produced in vitro," Animal Reproduction Science, vol. 70, no. 34, pp. 159-169, 2002.

[73] Y. Q. Yuan, A. van Soom, J. L. M. R. Leroy et al., "Apoptosis in cumulus cells, but not in oocytes, may influence bovine embryonic developmental competence," Theriogenology, vol. 63, no. 8, pp. 2147-2163, 2005.

[74] E. Warzych, E. Pers-Kamczyc, A. Krzywak, S. Dudzińska, and D. Lechniak, "Apoptotic index within cumulus cells is a questionable marker of meiotic competence of bovine oocytes matured in vitro," Reproductive Biology, vol. 13, no. 1, pp. 82-87, 2013.

[75] T. S. Hussein, D. A. Froiland, F. Amato, J. G. Thompson, and R. B. Gilchrist, "Oocytes prevent cumulus cell apoptosis by maintaining a morphogenic paracrine gradient of bone morphogenetic proteins," Journal of Cell Science, vol. 118, no. 22, pp. 5257-5268, 2005.

[76] I. Woclawek-Potocka, I. Kowalczyk-Zieba, M. Tylingo, D. Boruszewska, E. Sinderewicz, and D. J. Skarzynski, "Effects of lysophopatidic acid on tumor necrosis factor $\alpha$ and interferon $\gamma$ action in the bovine corpus luteum," Molecular and Cellular Endocrinology, vol. 377, no. 1-2, pp. 103-111, 2013.

[77] X. Ye, K. Hama, J. J. A. Contos et al., "LPA3-mediated lysophosphatidic acid signalling in embryo implantation and spacing," Nature, vol. 435, no. 7038, pp. 104-108, 2005.

[78] T. Kobayashi, "Effect of lysophosphatidic acid on the preimplantation development of mouse embryos," FEBS Letters, vol. 351, no. 1, pp. 38-40, 1994.

[79] J. W. Jo, B. C. Jee, C. S. Suh, and S. H. Kim, "Addition of lysophosphatidic acid to mouse oocyte maturation media can enhance fertilization and developmental competence," Human Reproduction, vol. 29, no. 2, pp. 234-241, 2014. 


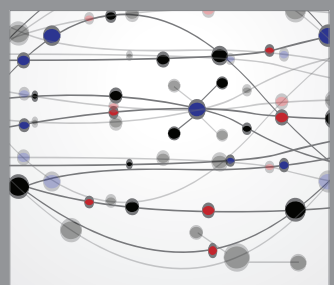

The Scientific World Journal
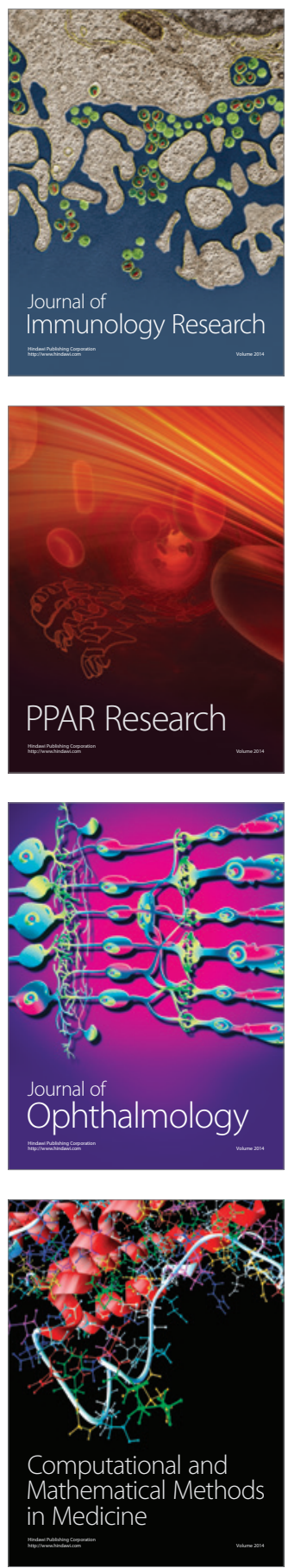

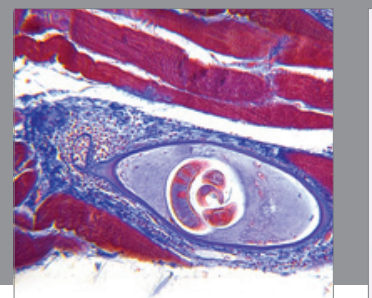

Gastroenterology

Research and Practice
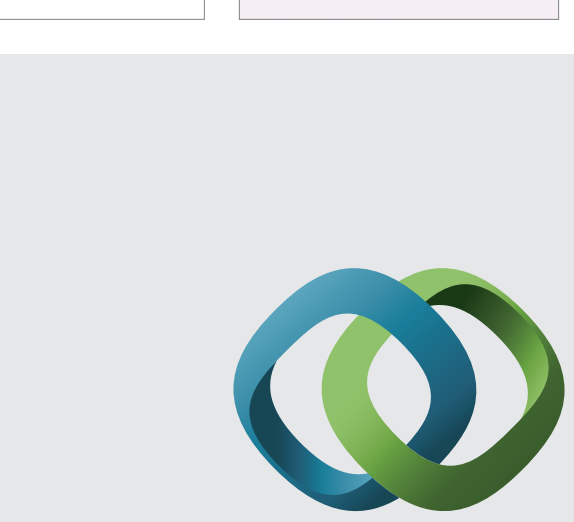

\section{Hindawi}

Submit your manuscripts at

http://www.hindawi.com
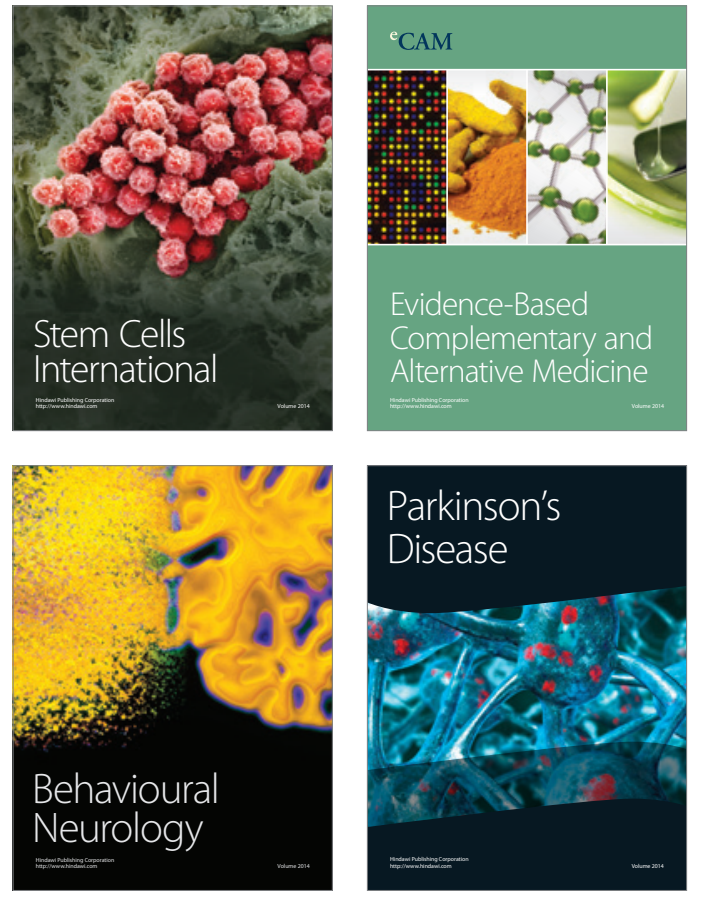
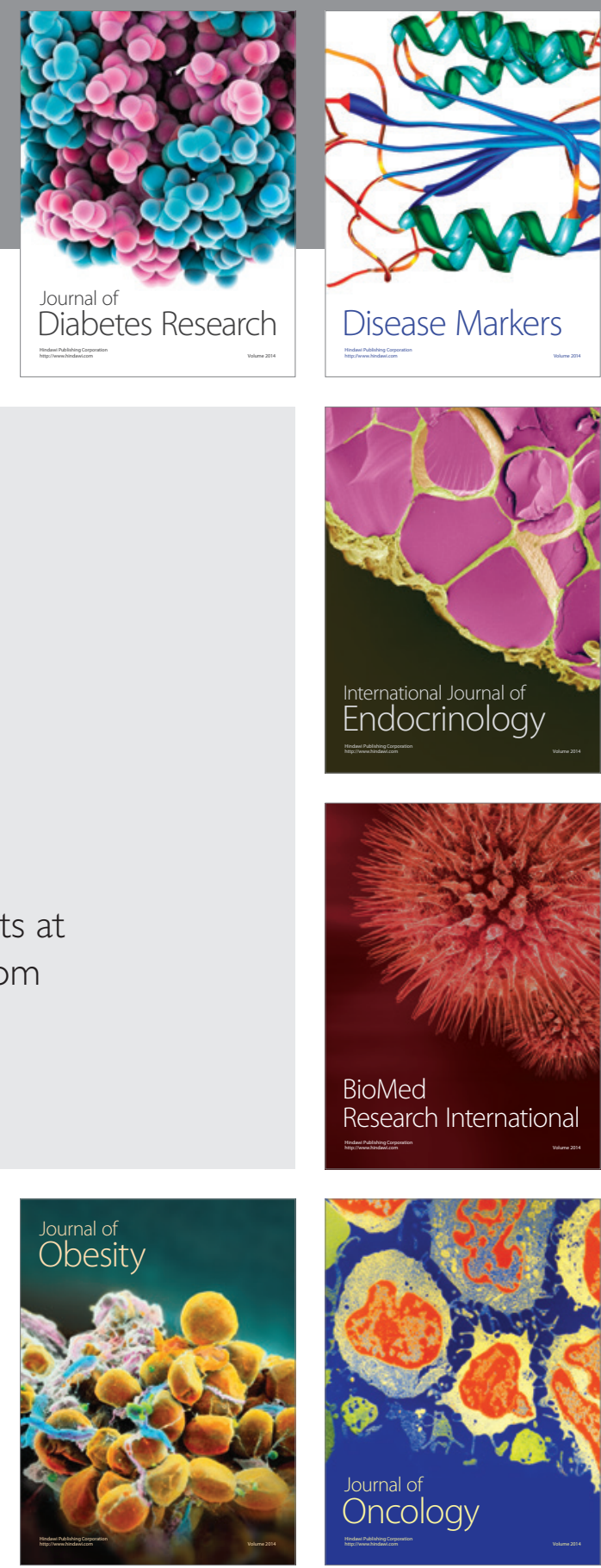

Disease Markers
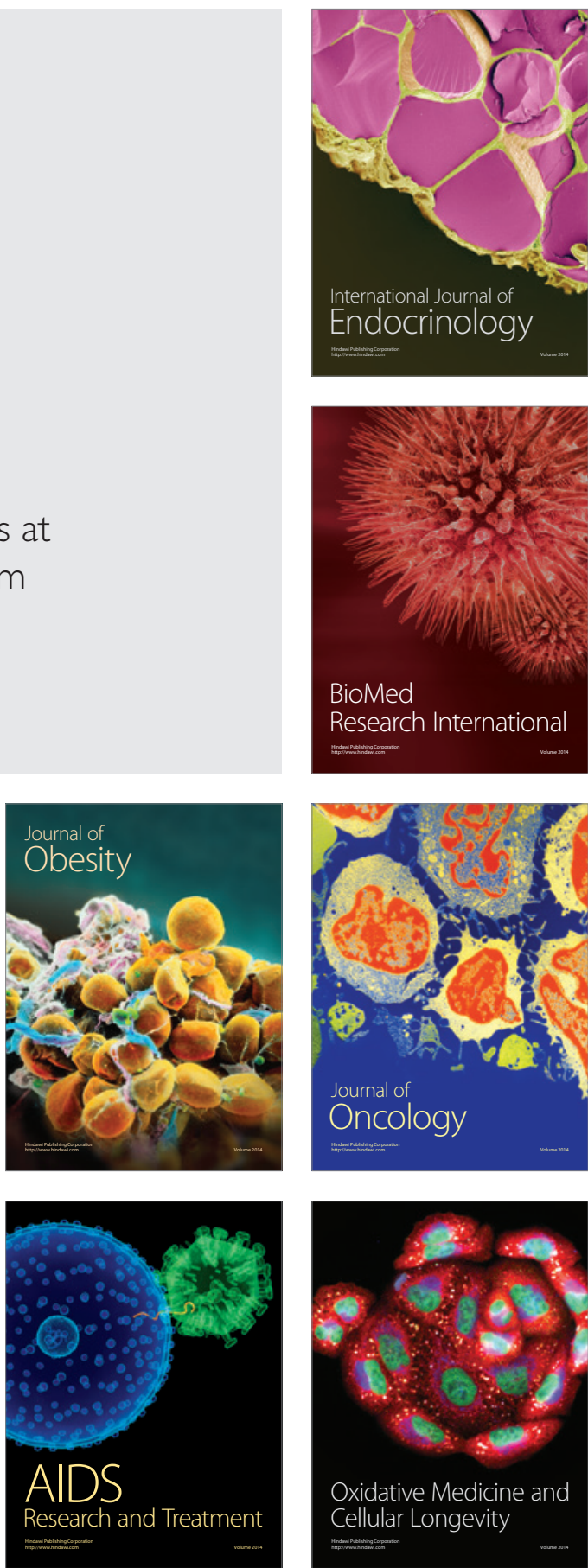